\title{
Steroid Regulation of Excitability in Identified Insect Neurosecretory Cells
}

\author{
Randall S. Hewes and J. W. Truman \\ Department of Zoology, University of Washington, Seattle, Washington 98195
}

In the moth Manduca sexta, the declining ecdysteroid titer on the final day of the molt from the fourth to the fifth larval instar acts on the ventromedial neurosecretory cells (VM cells) to stimulate the release of eclosion hormone (EH). EH then triggers the motor programs involved in ecdysis behavior. Intracellular recordings that were made from the VM cells throughout the intermolt and molting stages showed no spontaneous action potentials until $0.9 \mathrm{hr}$ before ecdysis (during the expected time of EH release), when $50 \%$ of the VM cells fired tonically at rest. This change was associated with a marked reduction in VM cell threshold without alteration of input resistance, resting potential, or synaptic drive. The increase in VM cell excitability was dependent on the declining ecdysteroid titer, because the injection of 20-hydroxyecdysone (20-HE) $\mathbf{1 1 . 5}$ hr before ecdysis significantly delayed the expected decrease in VM cell threshold. Since the same steroid treatment given $4.6 \mathrm{hr}$ before ecdysis did not delay the subsequent increase in VM cell excitability, the inhibitory actions of 20-HE appear not to be mediated by a rapid membrane mechanism. The possible involvement of genomic events in the steroid-dependent increase in VM cell excitability was examined using the RNA synthesis inhibitor actinomycin $D(A C D)$. When injected $6.3 \mathrm{hr}$ before ecdysis, $A C D$ blocked EH release without altering the response of the nervous system to exogenous peptide. Such AcD treatments also prevented the increase in VM cell excitability. These results suggest that the declining ecdysteroid titer increases the excitability of the VM cells via a transcription-dependent process.

IKey words: eclosion hormone, Manduca sexta, ecdysteroid, ecdysis, neuropeptide, 20-hydroxyecdysone, ventromedial neurosecretory cells (VM cells)]

Although steroid hormones play a major role in regulating the electrical activity of neurosecretory cells (NSCs) in a number of systems (e.g., Krey and Silverman, 1983; Zimmerman, 1983; Fink et al., 1991), the cellular mechanisms by which this regulation occurs remain elusive. Considerable progress has been

\footnotetext{
Received Feb. 3, 1993; revised Aug. 17, 1993; accepted Sept. 13, 1993.

This work was supported by NIH Training Grant GMD7108-14 to R.S.H., NSF Grant IBN8917310 to J.W.T., and NIH Instrumentation Grant S10RRO4646. We thank Janis Weeks for early technical support and encouragement, Bill Moody for the loan of equipment, and Steve Gammie, Kathy Graubard, Andrea Novicki, Cathy Pfister, Peter Schmidt, Troy Smith, and Dennis Willows for advice and assistance. We are also very grateful to James Baker, John Ewer, Bill Moody, Steve Robinow, and two anonymous reviewers for comments on the manuscript.

Correspondence should be addressed to Randall S. Hewes, Department of Anatomy and Neurobiology, Box 8108, Washington University School of Medicine, 660 South Euclid Avenue, St. Louis, MO 63110.
}

Copyright (C) 1994 Society for Neuroscience $0270-6474 / 94 / 141812-08 \$ 05.00 / 0$ made in the mapping of steroid hormone receptors to NSCs or their input neurons, and many of these cells exhibit steroiddependent alterations in receptor levels, synaptic and dendritic struclures, neurotransmitter or neuromodulator content, ultrastructure, or gene expression (for reviews, see McEwen and Parsons, 1982; Harlan, 1988; Naftolin et al., 1988; Fink, et al., 1991; McEwen et al., 1991). By contrast, few studies have described steroid-induced changes in the electrical activity of single NSCs. One notable exception is the work on the vertebrate hypothalamus, where estradiol and cortisol have been shown to reduce single-unit activity in rodent neurons that project to the median eminence (Dufy et al., 1976; Saphier and Feldman, 1990). These electrophysiological analyses, however, were limited to extracellular recordings of changes that occur rapidly in a heterogeneous sampling of NSCs. Here we report an insect preparation with large identifiable NSCs that provide a model for examining how genomic actions of steroids may lead to changes in NSC excitability.

Insect ecdysis behavior consists of a stereotyped pattern of movements used to shed the old cuticle at the end of a molt. In the tobacco hornworm, Manduca sexta, ecdysis is triggered by eclosion hormone (EH), a 62-amino acid neuropeptide that is produced by a set of four NSCs, the VM cells, located ventromedially in the brain (for a review, see Truman, 1992). These cells release EH only during a brief, $20-90 \mathrm{~min}$ period at the end of each molt (Reynolds et al., 1979; Truman et al., 1980; Copenhaver and Truman, 1982; Hewes and Truman, 1991). The steroid hormones, the ecdysteroids, are responsible for the initiation and coordination of the molt (Riddiford and Truman, 1978), and work on the pupal and adult ecdyses has shown that the declining steroid titer at the end of each molt provides the proximate hormonal trigger for EH release (Truman et al., 1983; Truman and Morton, 1990). At pupal ecdysis, EH release is prevented by pharmacological transcription and translation inhibitors (Truman and Morton, 1990), suggesting a mechanism in which the steroid decline triggers $E H$ release through a process that requires the synthesis of new RNA and protein.

We have recorded intracellularly from the VM cells of molting Manduca sexta larvae as an initial step in elucidating the cellular mechanisms underlying the control of VM cell excitability. During the expected period of $\mathrm{EH}$ release, there is a transient reduction in the VM cell threshold, and this change appears to require both the decline in circulating ecdysteroids and transcription.

\section{Materials and Methods}

Isolated brain preparation. Larval tobacco hornworms, Manduca sexta (Lepidoptera: Sphingidae), were reared individually on an artificial diet 


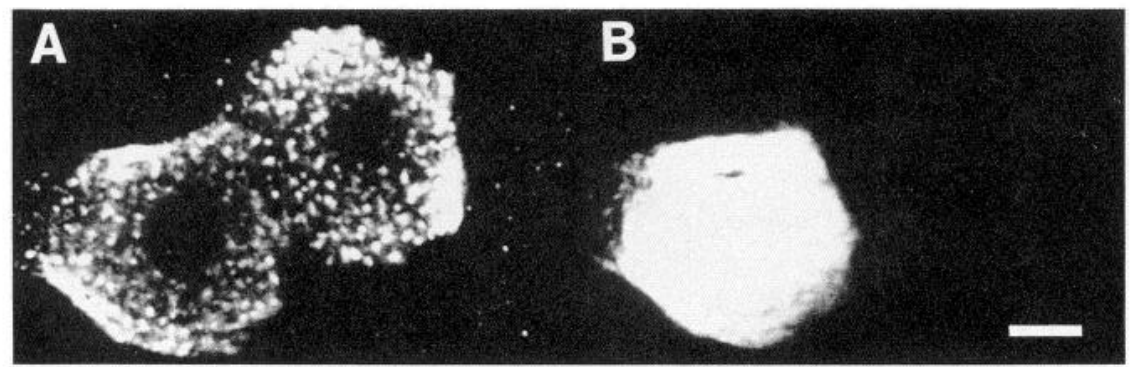

Figure 1. High-power confocal images of the medial portion of the brain of a larva molting from the fourth to the fifth instar, showing a cell that was intracellularly filled with biocytin in a brain that was subsequently immunostained using antibodies against EH. $A$, EH immunostaining. $B$, Pattern of biocytin staining in the same optical section as shown in $A$. One of the two cells was filled with the dye. (Similar results were obtained each of the five times that the double-labeling was attempted.) Scale bar, $10 \mu \mathrm{m}$.
(Bell and Joachim, 1976) at $26^{\circ} \mathrm{C}$ with either a short-day $(12 \mathrm{hr}$ light: $12 \mathrm{hr}$ dark) or a long-day (17 hr light:7 hr dark) photoperiod. Under these conditions, the duration of the fourth instar was approximately $107 \mathrm{hr}$, the first $57 \mathrm{hr}$ of which was intermolt [Gate II larvae (Truman, 1972)]. Animals molting from the fourth to the fifth larval instar were staged relative to the time of ecdysis $(0 \mathrm{hr})$ according to morphological and behavioral markers. These markers included the tan crochet stage $(-13.0 \mathrm{hr})$, the yellow mandible stage $(-9.8 \mathrm{hr})$, the air-filled brown mandible stage $(-5.6 \mathrm{hr})$, and the onset of pre-ecdysis behavior $(-1.4$ $\mathrm{hr}$ ), and are described in detail by Copenhaver and Truman (1982). In pilot experiments, changes in VM cell excitability were not observed following $\mathrm{CO}_{2}$ anesthesia and the associated 20-30 min delay in the establishment of intracellular recordings. Therefore, dissections were performed on unanesthetized caterpillars. The brain, plus the frontal, subesophageal, and first thoracic ganglia, was removed, arranged frontal surface up on a Sylgard-lined (Dow Corning, Midland, MI) petri dish, and stabilized with minutien pins. The ganglionic sheath was treated for 8-12 min with a solution of $1-5 \%$ collagenase/dispase (Boehringer Mannheim, Indianapolis, IN) in modified Miyazaki saline [in mM: 140 $\mathrm{NaCl}, 5 \mathrm{KCl}, 4 \mathrm{CaCl}_{2}, 28 \mathrm{D}$-glucose, $5 \mathrm{HEPES}$; $\mathrm{pH}$ was adjusted to 7.4 with $1 \mathrm{M} \mathrm{NaOH}$ (Miyazaki, 1980; Trimmer and Weeks, 1989)], and the preparation was rinsed with fresh saline.

Intracellular recording. When placed on a black background with oblique, fiber optic illumination, the 20-30 $\mu \mathrm{m}$ VM cell somata were visually identifiable in the intact brain under a dissecting microscope. Intracellular recordings were made within an average of $36 \mathrm{~min}(n=$ 93; range, 23-51 min) of starting the dissection. The somata were penetrated with 20-60 M $\Omega$, thick-walled, borosilicate glass microelectrodes filled with either $2 \mathrm{M} \mathrm{K}$-acetate or a biocytin $/ \mathrm{KCl}$ solution (see below). Penetrations were made through the residual sheath by either tapping on the micromanipulator or ringing the capacitance compensation on a Getting microelectrode amplifier (Getting Instruments, Iowa City, IA). Recordings were stored on a VHS recorder after digitization on an Instrutech VR-10 Digital Data Recorder (9600 baud; Instrutech Corporation, Mineola, NY). Data were analyzed off line using SuperScope (200 $\mu$ sec sample period; GW Instruments, Boston, MA). Statistics were performed with STATVIEW 512+ (Abacus Concepts, Berkeley, CA).

Currents were injected into the somata using standard amplifier bridge circuits (Araki and Otani, 1955; Frank and Fuortes, 1956; Ito, 1957). During the subsequent off-line analysis, the high resolution of the digitized data allowed us to determine the amplitude of any residual bridge imbalance errors. These were due either to under- or overcompensation of the bridge balance or to apparent changes in the resistance of the electrode during some recordings. These remaining errors were corrected by arithmetic subtraction of the near instantaneous component of each voltage record $(1.0 \pm 0.1 \mathrm{msec}$ time constant vs membrane time constant of $15.0 \pm 1.8 \mathrm{msec} ; n=10$ ), which was attributed to the potential drop across the resistance of the electrode (Araki and Otani, 1955), from the total voltage deflection measured during current injection. In control experiments, the slope input resistances $(n=7)$ and thresholds $(n=5$; see below) measured with this correction method were within $10 \%$ of those measured in the same cells with the bridge balanced as carefully as possible during the recording.

Each cell was stimulated with $600-1000 \mathrm{msec}$ hyperpolarizing and depolarizing current steps of varying magnitudes, with an interpulse interval of $3 \mathrm{sec}$. Slope input resistance was calculated from the linear portion of the current-voltage relation using small hyperpolarizing and depolarizing current steps. Threshold voltage was measured as the minimum depolarization from rest necessary to trigger the firing of an action potential. When cells fired tonically at rest, threshold was assumed to be $0 \mathrm{mV}$. Spike duration was measured at the maximum width of the action potential, and resting potential was measured upon electrode withdrawal from the cell. Recordings either from damaged cells, as indicated by low resting potentials, low input resistances, and reduced action potentials, or from cells in which the penetration was unstable, were discarded.

Histology. A $1.5 \%$ biocytin ( $\epsilon$-biotinoyl-L-lysine; Molecular Probes, Eugene, OR), $2 \mathrm{M} \mathrm{KCl}, 0.025 \mathrm{~m}$ Tris buffer solution (pH 7.5) was used to fill the tip of the recording electrode (Horikawa and Armstrong, 1988). The electrode shaft and electrode holder were then filled with $3 \mathrm{M} \mathrm{KCl}$. Biocytin was iontophoresed into cells with $1-3 \mathrm{~Hz}, 500 \mathrm{msec}, 1-5 \mathrm{nA}$ hyperpolarizing current pulses, and the ipsilateral longitudinal connectives posterior to the first or second thoracic ganglion were crushed to prevent further spread of the dye along the VM cell axon. After a 30$60 \mathrm{~min}$ incubation period in saline, the tissues were fixed in $4 \%$ paraformaldehyde in phosphate-buffered saline (PBS; Truman and Copenhaver, 1989) for about $14 \mathrm{hr}$ at room temperature. The samples were then repeatedly rinsed in PBS with $0.3 \%$ Triton X-100 (PBS-TX; Sigma, St. Louis, MO), run up and down a graded methanol series, and preincubated for $1 \mathrm{hr}$ at room temperature in $10 \%$ heat inactivated normal goat serum (Sigma) in PBS-TX. For colocalization of biocytin and EH immunoreactivity, brains were incubated with a rabbit polyclonal antiserum to EH (Copenhaver and Truman, 1986) at a 1:1000 dilution (Hewes and Truman, 1991) for $72 \mathrm{hr}$ at $4^{\circ} \mathrm{C}$. Following incubation in the primary antiserum, brains were incubated in 1:200 FITC-conjugated, goat anti-rabbit immunoglobulin (Vector Laboratories, Burlingame, CA) in PBS-TX for $72 \mathrm{hr}$ at $4^{\circ} \mathrm{C}$, with agitation. The tissues were washed in PBS-TX and incubated at room temperature with agitation in 1:200 avidin-Texas Red conjugate (Vector Laboratories) in PBS-TX for $18 \mathrm{hr}$. Tissues were then washed in PBS, mounted in $80 \%$ glycerol in PBS with $2 \% n$-propyl gallate and examined on a Bio-Rad (MRC600 ) confocal imaging system.

Hormone and drug treatments. Injections were performed with 28 gauge, 25-100 $\mu$ l syringes (Unimetrics Corporation, Shorewood, IL) into abdominal prolegs. 20-Hydroxyecdysone (20-HE; Sigma) was dissolved at $0.6 \mu \mathrm{g} / \mu \mathrm{l}$ in $10 \%$ isopropanol and checked spectrophotometrically at $240 \mathrm{~nm}(\epsilon=12,670)$. Actinomycin D (AcD; Sigma) was dissolved at 1 $\mu \mathrm{g} / \mu \mathrm{l}$ in $100 \% \mathrm{EtOH}$. Recombinant EH(Eldridge et al., 1991), containing 0.5 units activity $/ \mu 1$, was diluted in $10 \%$ acetonitrile in saline (Ephrussi and Beadle, 1936), with $0.1 \mathrm{mg} / \mathrm{ml}$ bovine serum albumin (Sigma), to a final concentration of $0.1 \mathrm{U} / \mu \mathrm{l}$. A unit of $\mathrm{EH}$ was defined as the amount present in the corpora cardiaca-corpora allata complex of one pharate adult $M$. sexta [approximately $0.5 \mathrm{pmol}$ (Terzi et al., 1988)]. All injection volumes were $5 \mu \mathrm{l}$.

EH bioassay. Sets of five terminal ganglia with the attached proctodeal nerves (PN) were removed from staged, ice-anesthetized larvae, and EH was extracted from the pooled tissues as described by Terzi et al. (1988). The amount of $\mathrm{EH}$ in each extract was then determined on serially diluted samples (in saline with $20 \%$ acetonitrile) that were subjected to the EH pupal bioassay (Truman et al., 1980).

\section{Results}

\section{$V M$ cell identification}

In the CNS of larval $M$. sexta, $\mathrm{EH}$ is produced by a total of four neurons [the VM cells (Horodyski et al., 1989; Truman and Copenhaver, 1989; Hewes and Truman, 1991)]. The 20$30 \mu \mathrm{m}$ somata of these cells are located ventromedially on the 

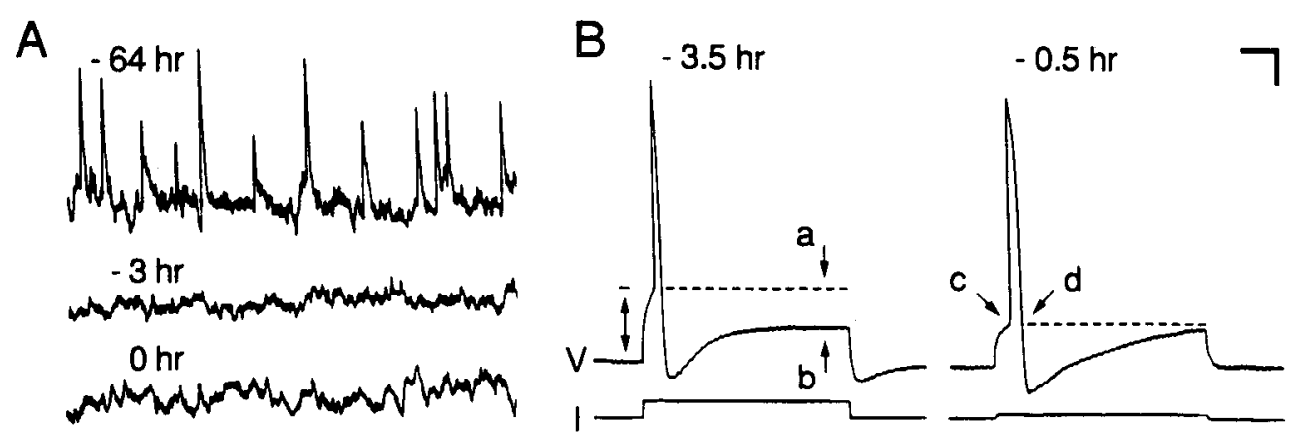

Figure 2. Intracellular recordings from the VM cell somata. $A$, Synaptic activity observed $64 \mathrm{hr}$ (during the intermolt), $3 \mathrm{hr}$, and $0 \mathrm{hr}$ before ecdysis. $B$. Action potentials at $-3.5 \mathrm{hr}$ and at -0.5 $\mathrm{hr}$, during the time of $\mathrm{EH}$ release. Threshold voltage (double arrow), plateau voltage $(a-b)$, and spike duration $(d-c)$ was measured as shown. $C$, Transient decreases (asterisks) in the input resistance measured with brief, $100 \mathrm{pA}$ current pulses. Note the large plateau voltage (dashed line indicates spike onset voltage). $D$, Repetitive firing properties at $-3.5 \mathrm{hr}$ and at -0.5 hr (left, no firing at rest; right, tonic firing at rest). The spike amplitude ratio was measured as shown $(f \div e)$. $V$, membrane potential; $I$, applied current. Calibration: $A, 200 \mathrm{msec}, 1 \mathrm{mV} ; B, 100$ msec, $10 \mathrm{mV}, 1 \mathrm{nA} ; C, 475 \mathrm{msec}, 9.5$ $\mathrm{mV}, 0.95 \mathrm{nA} ; D$, left, $200 \mathrm{msec}, 25 \mathrm{mV}$, $1.4 \mathrm{nA} ; D$, center, $200 \mathrm{msec}, 10 \mathrm{mV}, 1$ $\mathrm{nA} ; D$, right, $1.1 \mathrm{sec}, 10 \mathrm{mV}$.
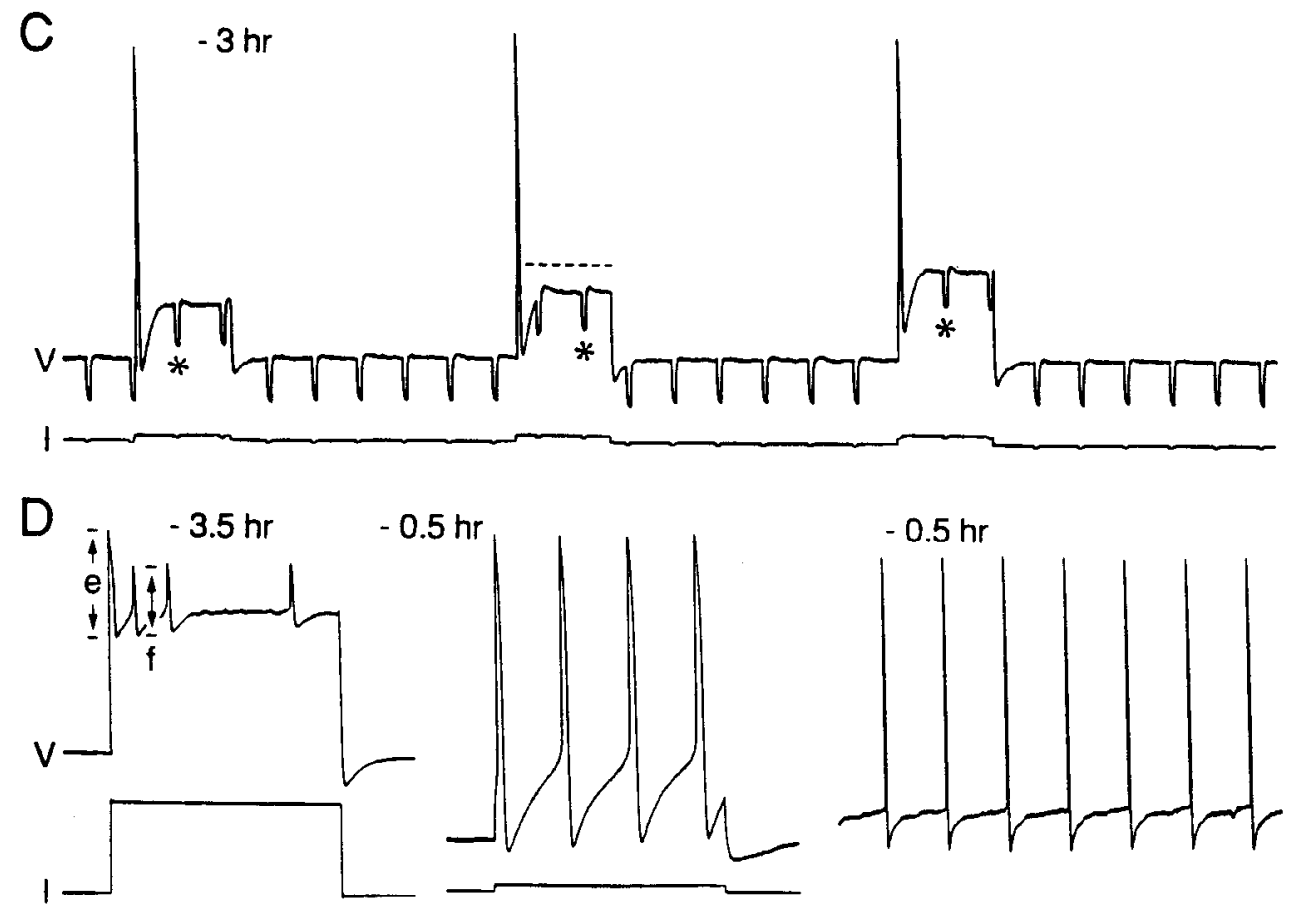

frontal surface of the brain. Viewed under the dissecting microscope, the VM cell somata were translucent and dark, while most of the neighboring cells were opaque and white. The VM cell somata were also about twice the diameter of the adjacent neurons. This visual identification was confirmed by intracellular iontophoresis of biocytin through the recording electrode and subsequent demonstration that the injected dye was located in EH-immunopositive neurons (Fig. 1).

\section{Intracellular recordings}

Changes in VM cell excitability. We first examined the electrophysiological properties of the VM cells in isolated CNS preparations obtained during the intermolt period (approximately $64 \mathrm{hr}$ before ecdysis). In intracellular recordings, $1-4 \mathrm{mV}, 2-3$ $\mathrm{Hz}$, depolarizing postsynaptic potentials (PSPs) were observed in three of seven preparations (Fig. 2A). These PSPs were excitatory (EPSPs), because their estimated reversal potentials were positive to threshold. However, the EPSPs failed to initiate action potentials at rest. Spontaneous firing of the VM cells was not observed during the intermolt.

With the injection of depolarizing current, the intermolt VM cell somata fired all or none, overshooting action potentials at a mean threshold of $13 \mathrm{mV}$ positive with respect to the resting membrane potential ( $V_{\text {rest }}$; Figs. $2 B, 3 A$ ). Near threshold, the intermolt VM cells accommodated very rapidly, generating only a single action potential during maintained depolarizations. Following spikes elicited at threshold, the membrane potential stabilized at a plateau $10 \mathrm{mV}$ negative to the value at the action potential onset (Figs. $2 B, 3 C$ ). This "plateau voltage" was maintained for the remainder of the current pulse, regardless of duration $(0.2-5.0 \mathrm{sec})$, and involved a $10-15 \%$ decrease in input resistance (Fig. $2 C$ ). After the cell was returned to $V_{\text {rest }}$, subsequent equal magnitude depolarizations again triggered single spikes. Larger suprathreshold depolarizations sometimes elicited multiple action potentials, but the amplitudes of the later spikes were much smaller than that of the first (Fig. 2D). Measured at the minimum depolarization necessary to evoke repetitive firing, the "spike amplitude ratio" (second spike amplitude/first spike amplitude) was only 0.78 (Fig. $3 \mathrm{D}$ ).

The low level of excitability of the VM cells was maintained throughout the intermolt and most of the molt. In preparations selected $3.2 \pm 0.4 \mathrm{hr}$ before ecdysis ( $\pm \mathrm{SE} ; n=14$ ), these cells still showed thresholds, spike durations, plateau voltages, and spike amplitude ratios similar to the intermolt values (Fig. 3). However, in preparations examined $0.9 \pm 0.1 \mathrm{hr}( \pm \mathrm{SE})$ before ecdysis [during pre-ecdysis behavior, the first overt response to EH release (Copenhaver and Truman, 1982; Miles and Weeks, $1991) ; n=10]$, the VM cells showed a marked increase in 

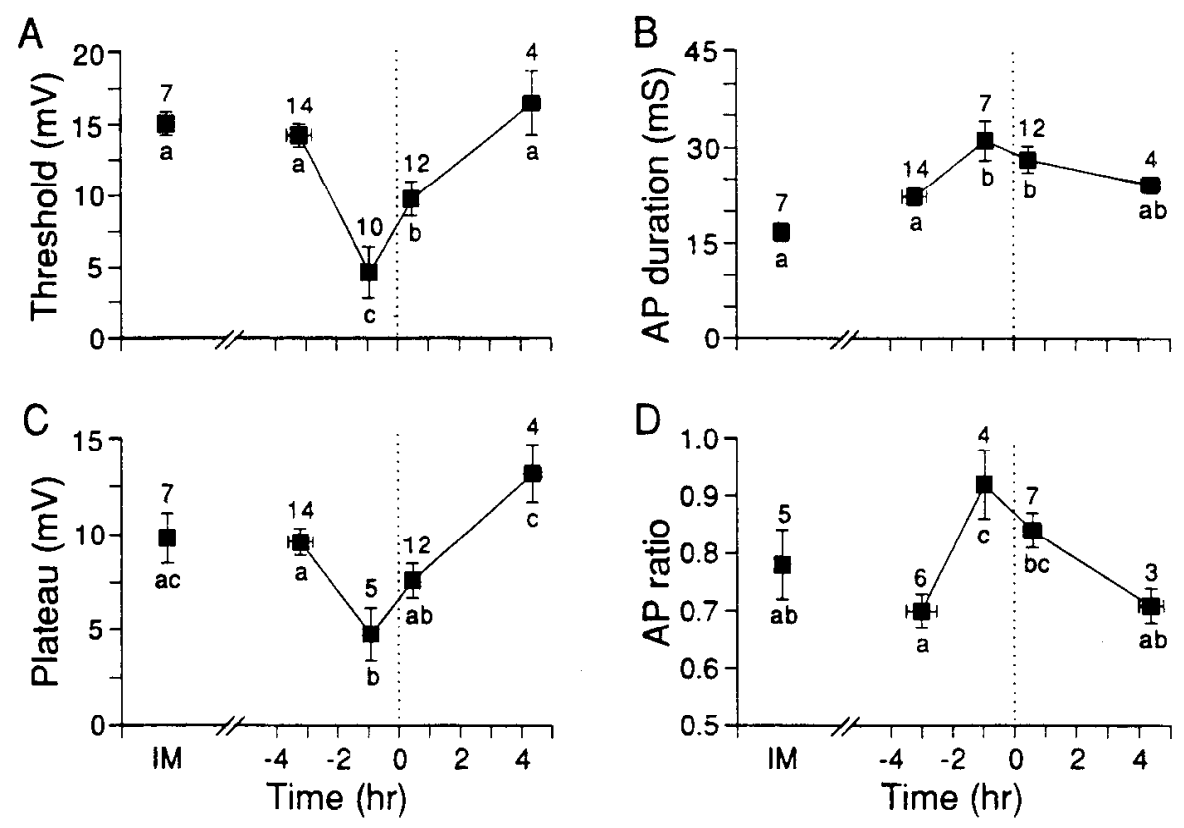

Figure 3. Changes in electrical properties of the VM cells as a function of time relative to ecdysis $(0 \mathrm{hr})$. $A$, Mean threshold voltage. $B$, Mean action potential duration. $C$, Mean plateau voltage. $D$, Mean spike amplitude ratio. Means with the same letter designation are not significantly different $[p \geq 0.05$; one-way ANOVA, Fisher protected least significant difference (PLSD)]. Error bars represent $\pm \mathrm{SE}$ ( $n$ shown with each mean); $I M$, intermolt ( $-64 \mathrm{hr})$; dotted line, ccdysis.

excitability without a significant alteration in input resistance, $V_{\text {rest }}$, or action potential amplitude (Table 1). Threshold in these cells was dramatically reduced (Fig. $3 A$ ), and $50 \%$ of them fired tonically at $0.6-2.0 \mathrm{~Hz}$ at rest (Fig. $2 D$ ). In addition, the mean action potential duration was increased, the mean plateau voltage was decreased, and the mean spike amplitude ratio was nearly 1.0 (Fig. $3 B-D$ ). There was no detectable increase in synaptic drive, and the large EPSPs observed in some of the intermolt preparations were never observed in any of the recordings around the time of ecdysis (Fig. $2 A$ ). The changes in threshold, action potential duration, plateau voltage, and spike amplitude ratio persisted through the time of ecdysis, but by $4.4 \pm 0.3 \mathrm{hr}$ after ecdysis ( $\pm \mathrm{SE} ; n=4)$, spontaneous firing had ceased, and the cells had returned to the intermolt levels of excitability. Thus, the VM cells show a transient change in excitability that coincides with peptide release, and this change appears to be effected primarily by a dramatic reduction in spike threshold.

\section{Ecdysteroid control of VM cell excitability}

During the molt from the fourth to the fifth larval instar, the ecdysteroid titer reaches peak levels at approximately $21 \mathrm{hr}$ before ecdysis and declines thereafter. The injection of 20-HE early during this decline results in a dose-dependent delay of ecdysis behavior (Curtis et al., 1984). Early 20-HE injection also delays ecdysis to the pupa, and this is accompanied by a delay in the release of EH (Truman and Morton, 1990). Therefore, we tested the hypothesis that steroid treatment would delay the increase in the excitability of the VM cells. Larvae injected with $3 \mu \mathrm{g}$ of $20-\mathrm{HE}$ at $-11.5 \mathrm{hr}(n=21)$ subsequently ecdysed 2.5 $\pm 0.1 \mathrm{hr}( \pm \mathrm{SE})$ later than vehicle-injected controls $(n=12)$. At their normal time of ecdysis (as indicated by the matched, injected controls) these animals still exhibited the high threshold, short action potential duration, large plateau voltage, and reduced spike amplitude ratio characteristic of intermolt animals (Fig. 4, solid squares). Importantly, $2.5 \mathrm{hr}$ later, when the treated animals finally ecdysed, their VM cells had acquired the excitability characteristic of controls at $0.9 \mathrm{hr}$ before ecdysis (Fig.
4). Thus, this early ecdysteroid treatment delays the increase in VM cell excitability.

During each molt the nervous system becomes "committed" to undergo ecdysis a number of hours before the behavior actually begins. Ecdysteroid treatment after this commitment time is ineffective in delaying the behavior (Truman et al., 1983; Curtis et al., 1984). For both the pupal and the adult molts, this commitment time appears to represent the time when ecdysteroid treatment can no longer delay the release of EH (Truman et al., 1983; Truman and Morton, 1990). Therefore, we expected that ecdystcroid treatment after commitment would not delay the increase in excitability of the VM cells. During the molt from the fourth to the fifth larval instar, commitment occurs at $7 \mathrm{hr}$ before ecdysis (Curtis et al., 1984), and as seen in Figure 4 (open squares), the injection of 20-HE at $4.6 \mathrm{hr}$ before ecdysis did not delay the increase in VM cell excitability. Therefore, this increase is not blocked by the contemporaneous presence of steroid. Rather, the steroid-sensitive events that lead to these excitatory changes must occur 5-6 hr earlier.

\section{The role of transcription in VM cell excitation}

To test whether the increase in VM cell excitability involved transcription-dependent events, we injected the RNA synthesis

Table 1. Mean input resistance, resting potential, and action potential amplitude in intermolt and molting larvae

\begin{tabular}{lrlll}
$\begin{array}{l}\text { Time relative } \\
\text { to ecdysis } \\
(\mathrm{hr} \pm \mathrm{SE})\end{array}$ & \multicolumn{1}{c}{$n$} & $\begin{array}{l}\text { Input } \\
\text { resistance } \\
(\mathrm{M} \Omega \pm \mathrm{SE})\end{array}$ & $\begin{array}{l}\text { Resting } \\
\text { potential } \\
(\mathrm{mV} \pm \mathrm{SE})\end{array}$ & $\begin{array}{l}\text { Action } \\
\text { potential } \\
\text { amplitude } \\
(\mathrm{mV} \pm \mathrm{SE})\end{array}$ \\
\hline-64 & 7 & $76.0 \pm 9.0$ & $-38.3 \pm 1.1$ & $70.3 \pm 2.4$ \\
$-3.2 \pm 0.4$ & 14 & $55.6 \pm 4.5$ & $-36.6 \pm 1.2$ & $68.3 \pm 2.9$ \\
$-0.9 \pm 0.1$ & 9 & $64.8 \pm 11.4$ & $-33.3 \pm 2.1$ & $68.4 \pm 5.6$ \\
$0.5 \pm 0.2$ & 12 & $54.5 \pm 6.7$ & $-38.3 \pm 1.5$ & $71.3 \pm 2.0$ \\
$4.4 \pm 0.3$ & 4 & $65.8 \pm 8.2$ & $-38.6 \pm 2.3$ & $71.8 \pm 2.7$
\end{tabular}

Differences between groups were not significant (one-way ANOVA, $P>0.05$ ). 


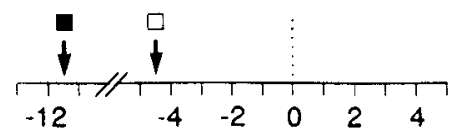

Figure 4. Effects of the timing of 20 HE treatment on the electrical properties of the VM cells. $A$, Mean threshold voltage. Scale shows the times of the carly (solid squares) and late (open squares) 20-HE treatments. B, Mean action potential duration. $C$, Mean plateau voltage. $D$, Mean spike amplitude ratio. In each panel, values from control preparations (data taken from Fig. 3) are plotted as a solid line (ecdysis in vehicle-injected controls at $0 \mathrm{hr}$ ). The means obtained at $t=0 \mathrm{hr}$ for both the early and late 20 -HE treatments were compared to the control value from Figure 3 at $t=-0.9 \mathrm{hr}$; the $t=2.4 \mathrm{hr}$ mean for the early 20 -HE treatment was compared to the control value from Figure 3 at $t=4.4 \mathrm{hr}$ (one-way ANOVA, Fisher PLSD). Error bars represent $\pm \mathrm{SE}$ ( $n$ shown with each mean); dotted line, ecdysis (control). $*, p \leq 0.05 ; * *$, $p \leq 0.01 ; * * *, p \leq 0.001$.
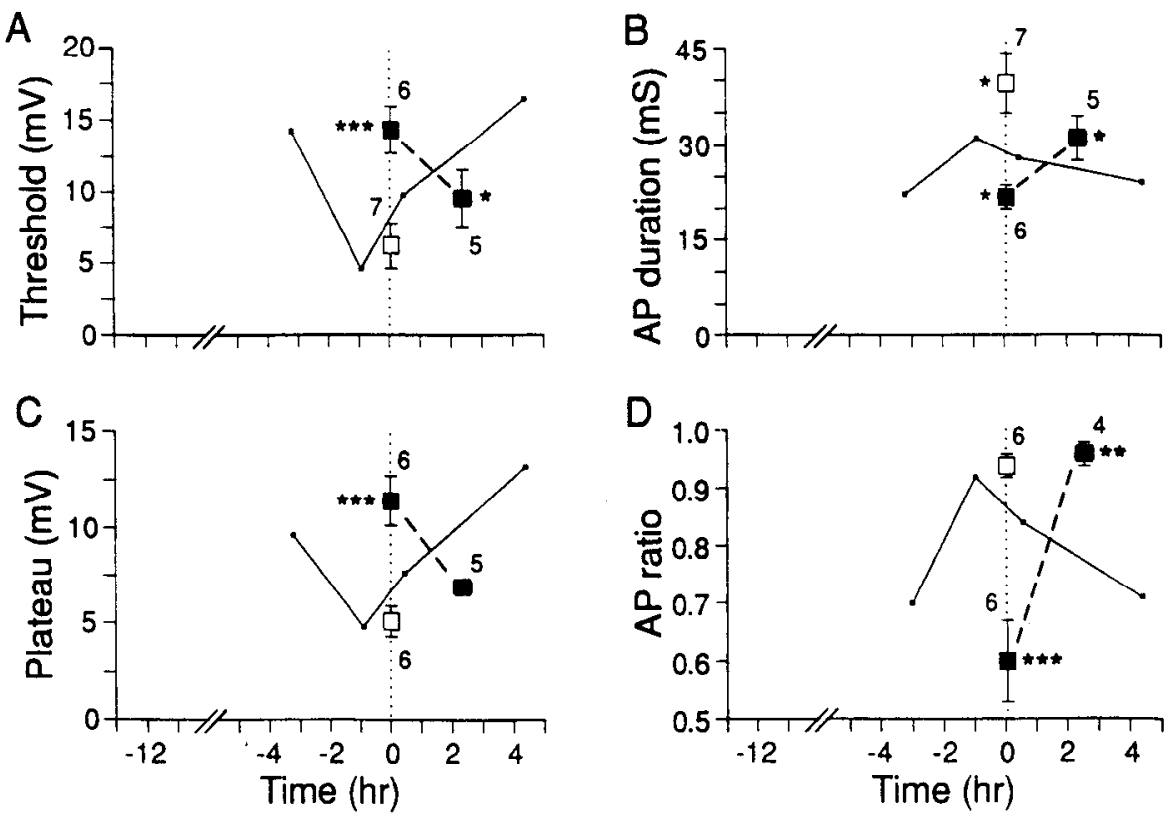

inhibitor AcD into molting larvae. Injections of $5 \mu \mathrm{g}$ of $\mathrm{AcD}$ per larva blocked ecdysis in a time-dependent manner (Fig. 5). The time of half-effectiveness $\left(\mathrm{ET}_{50}\right)$ was $-4.5 \mathrm{hr}$. Since the $\mathrm{ET}_{50}$ for the 20-HE-induced delay of ecdysis is $-7 \mathrm{hr}$ (Curtis et al., 1984), these larvae remained sensitive to AcD for $2.5 \mathrm{hr}$ after the declining ecdysteroid titer initiated the programming for $\mathrm{EH}$ release.

The nature of the AcD-induced blockage was examined by extraction and bioassay of the $\mathrm{EH}$ activity contained in the neurohemal release site, the PN (Truman and Copenhaver, 1989; Truman and Morton, 1990; Hewes and Iruman, 1991). In con-

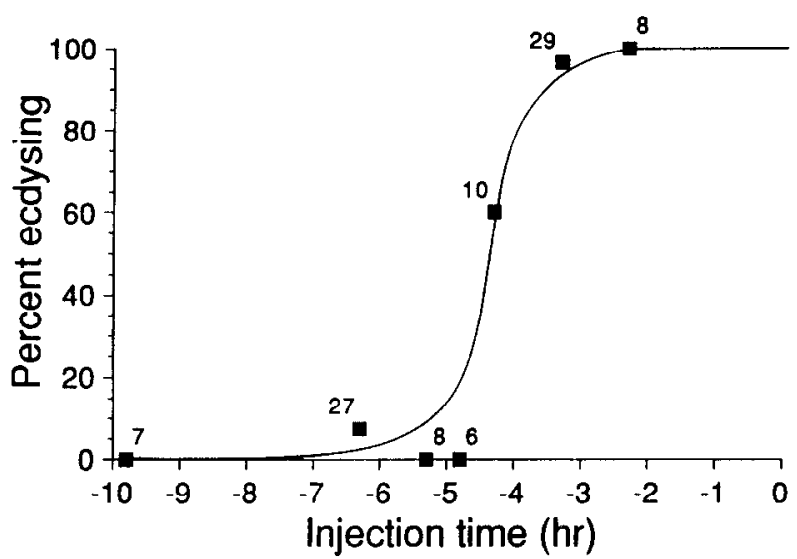

Figure 5. Percentage of animals showing ecdysis behavior following AcD treatment. Larvae were injected at the times indicated $(0 \mathrm{hr}$ was the time of ecdysis in uninjected control larvae), and animals were scored as having ecdysed if they were observed either performing the behavior or to have shed at least some of the old cuticle (or tracheae) during the $24 \mathrm{hr}$ period following the normal time of the behavior. The number of animals used at each point is indicated. All control vehicle-injected animals ecdysed (not shown; $n \geq 6$ for each group). trol animals, the amount of EH activity in the PN dropped by $>90 \%$ during the $6 \mathrm{hr}$ period preceding ecdysis to the fifth instar. This depletion was also evident in vehicle-injected controls that were examined at either $3.2 \mathrm{hr}$ or $11.2 \mathrm{hr}$ after ecdysis. However, the PN from larvae injected with $5 \mu \mathrm{g}$ of $\mathrm{AcD}$ at $-6.3 \mathrm{hr}$ and examined 3.2 or $11.2 \mathrm{hr}$ after the expected time of ecdysis still contained essentially the full complement of $\mathrm{EH}$, indicating that the normal EH release was blocked (Fig. 6).
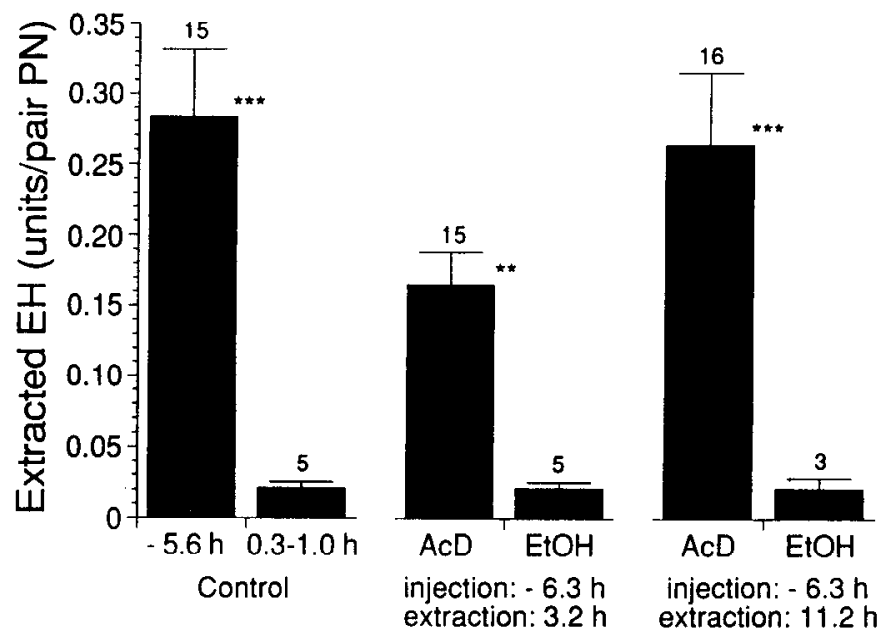

Figure 6. Effects of AcD on the depletion of EH activity from the PN. Larvae were injected with $A c D$ or vehicle (EtOH) $6.3 \mathrm{hr}$ before ecdysis. The amount of extracted $\mathrm{EH}$ activity was determined for control animals dissected either at $-5.6 \mathrm{hr}$ or at $0.3-1.0 \mathrm{hr}$ and for AcD- or vehicletreated animals dissected $3.2 \mathrm{hr}$ or $11.2 \mathrm{hr}$ after the normal time of ecdysis (based on the vehicle-injected controls). Paired means were significantly different (Mann-Whitney; ${ }^{* *}, p \leq 0.01$; ***, $p \leq 0.001$ ). However, the means for each of the AcD treatments were not significantly different from the control mean at $-5.6 \mathrm{hr}(p \geq 0.05$; one-way ANOVA). Error bars represent $\pm \mathrm{SE}$ ( $n$ shown with each mean). 

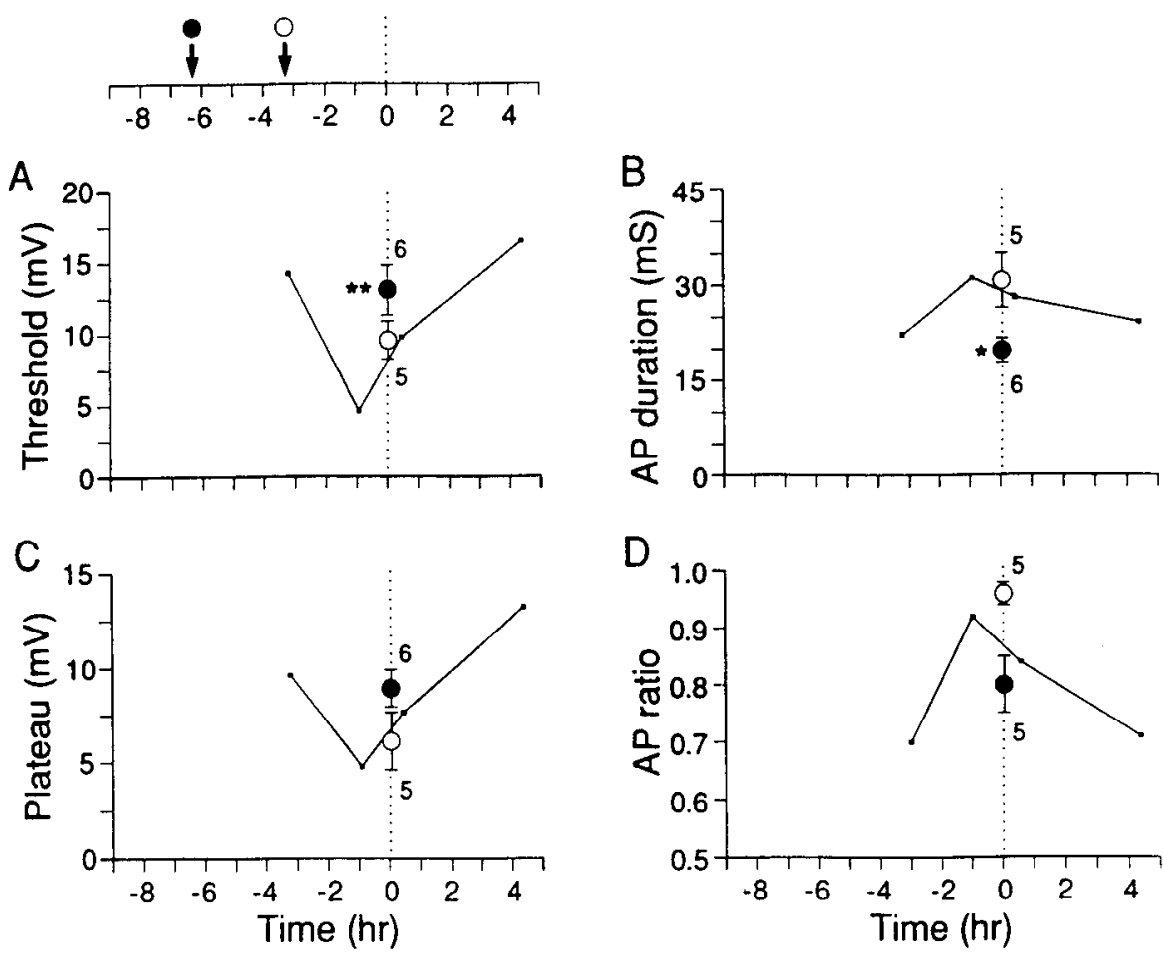

\begin{abstract}
Figure 7. Effects of the timing of $\mathrm{AcD}$ treatment on the electrical properties of the VM cells. $A$, Mean threshold voltage. Scale shows time of early (solid circles) and late (open circles) administration of AcD. B, Mean action potential duration. $C$, Mean plateau voltage. $D$, Mean spike amplitude ratio. In each panel, values from control preparations (data taken from Fig. 3) are plotted as a solid line (ecdysis in vehicle-injected controls at $0 \mathrm{hr}$ ). The means obtained at $t=0 \mathrm{hr}$ for both of the AcD treatments were compared to the control value from Figure 3 at $t--0.9 \mathrm{hr}$ (oneway ANOVA, Fisher PLSD). Error bars represent $\pm \mathrm{SE}$ ( $n$ shown with each mean); dotted line, ecdysis (control). *, $p \leq 0.05$; $^{* *}, p \leq 0.01$; ${ }^{* *}, p \leq 0.001$.
\end{abstract}

Despite the block of EH release, the AcD-treated animals were competent to ecdyse when challenged with exogenous $\mathrm{EH}$. After injection of $5 \mu \mathrm{g}$ of $\mathrm{AcD}$ at $-6.3 \mathrm{hr}$, larvae were subsequently injected at $-1.6 \mathrm{hr}$ with 0.5 units of recombinant $\mathrm{EH}$ (Eldridge et al., 1991). Most of the larvae $(71 \%)$ then showed ecdysis behavior with an average latency of $1.3 \pm 0.1 \mathrm{hr}( \pm \mathrm{SE} ; n=7)$. Thus, $\mathrm{AcD}$ given during this time window did not block the ability of these animals to respond to $\mathrm{EH}$, but rather blocks the release of the peptide itself.

The AcD treatment at $-6.3 \mathrm{hr}$ also prevented the changes in excitability of the VM cells (Fig. 7, solid circles). At their expected time of ecdysis (based on matched $\mathrm{EtOH}$-injected controls), the VM cells of these larvae showed the relative inexcitability characteristic of intermolt animals. The effect of this $\mathrm{AcD}$ treatment was weaker than that observed with 20 -HE treatment. This result may reflect either the completion of some events required for the changes in excitability prior to $-6.3 \mathrm{hr}$ or an incomplete block of these changes by the $\mathrm{AcD}$ treatment. Importantly, the same dose of AcD presented $3.3 \mathrm{hr}$ before ecdysis failed to prevent the subsequent increase in VM cell excitability (Fig. 7, open circles). Therefore, AcD can interfere with the acquisition of these changes only if it is present through the period in which the cells are hecoming steroid independent.

\section{Discussion}

During a $4.5 \mathrm{~d}$ period preceding ecdysis of $M$. sexta to the fifth larval instar, EH is stockpiled throughout the VM cell arbor (Truman et al., 1981; Truman and Copenhaver, 1989). On the last day of the molt, more than $95 \%$ of the peptide store is released during a brief period immediately preceding ecdysis (Fig. 6; see also Truman and Copenhaver, 1989; Truman and Morton, 1990; Hewes and Truman, 1991). Our results from intracellular recording show that this process involves an ecdysteroid-dependent reduction in spike threshold of the VM cells. The events leading to these changes in VM cell excitability also appear to require the synthesis of new RNA and protein, although the nature and location of this synthesis is unknown.

\section{Changes in VM cell excitability}

The VM cell somata were electrically active and fired all or none, overshooting action potentials. This feature is characteristic of insect NSCs and is rarely observed in other CNS neurons (Miyazaki, 1980; Orchard and Loughton, 1985; Pichon and Ashcroft, 1985). The VM cells also had low resting potentials $(-33$ to $-39 \mathrm{mV})$. These values did not appear to be due to penetration damage, because they were observed in recordings in which the input resistance, spike amplitude, spike duration, and $V_{\text {resi }}$ all remained stable for more than an hour. Moreover, resting potentials in this range have been documented for several different NSCs in a diverse sampling of insects (Orchard and Loughton, 1985).

The most dramatic change associated with the increase in VM excitability was a decrease in threshold. Four intrinsic membrane properties could be involved in this decrease: an increase in input resistance (which was not obscrved), an incrcasc in an inward current, a decrease in an outward current, or the modulation of a current involved near threshold but not in spike generation per se. Concomitant with the decrease in threshold, the VM cells displayed an increase in action potential duration, a decrease in the plateau voltage, and an increase in the spike amplitude ratio. The increase in the duration of the action potential was not due to activity-dependent spike broadening (Aldrich et al., 1979), because it was clearly evident even in cells that were inhibited from firing for several minutes. The large plateau voltage and reduced spike amplitude ratio characteristic of intermolt cells were correlated with a decreased input resistance, which could have been the result of incompletely inactivating outward currents. Such currents would tend to shunt 
subsequent action potentials as they propagate into the soma from a remote spike initiation zone and would lower the spike amplitude ratio. Because these currents would also be likely to decrease with reduced depolarization, the changes in the plateau voltage and spike amplitude ratio at -0.9 hr may have been secondary to the associated decrease in threshold.

We saw no evidence for the synaptic control of VM cell firing at the time of $\mathrm{EH}$ release. We cannot rule out, however, the possibility of an electrically distant spike initiation zone (or zones), and FPSPs sufficient to trigger spiking at these sites may not be detectable at the soma. In addition, factors involved in the setup of the isolated brain preparation may have either removed the source of some inputs or masked their effects. It is unclear why EPSPs observed during the intermolt were never observed during the molt.

Only $50 \%$ of the cells recorded at $0.9 \mathrm{hr}$ before ecdysis (during pre-ecdysis behavior) fired tonically at rest. Because pre-ecdysis is triggered by EH release (Copenhaver and Truman, 1982; Miles and Weeks, 1991), the VM cells most likely fire for a period of time before an overt behavioral response is observed. Circulating levels of $\mathrm{EH}$ also begin to decline at around the time of ecdysis (Keynolds et al., 1979; Iruman et al., 1980; Copenhaver and Truman, 1982; Hewes and Truman, 1991), and the halflife for EH degradation in the blood is approximately $45 \mathrm{~min}$ (Reynolds et al., 1979). Thus, firing activity in the VM cells may begin to decline before ecdysis behavior actually hegins, and the VM cells may be most active near the beginning of preecdysis. Given also the delay in recording and possible deterioration of the preparations following dissection, it is not surprising that the proportion of actively firing cells was less than $100 \%$.

\section{$V M$ cell excitability is dependent on declining ecdysteroids}

At $-7 \mathrm{hr}$, the ecdysteroid titer declines below a threshold level (Curtis et al., 1984), and the nervous system is committed to proceed with EH release (Truman et al., 1983; Truman and Morton, 1990). Prior to this time, the injection of 20-HE causes a dose-dependent delay in the release of EH. The injection of $3 \mu \mathrm{g}$ of $20-\mathrm{HE}$ per larva at $-11.5 \mathrm{hr}$ delayed ecdysis by $2.5 \mathrm{hr}$, a delay consistent with the results of Curtis et al. (1984). This early 20-HE injection also delayed the normal increase in the excitability of the VM cells (Fig. 4). Importantly, ecdysteroids appear not to regulate VM cell excitability through rapid membrane mechanisms (for reviews, see Schumacher, 1990; McEwen, 1991; Hutchison, 1991), because the late $-4.6 \mathrm{hr}$ injection of $20-\mathrm{HE}$ had no effect on the subsequent appearance of these changes. On the basis of these results and the data of Curtis et al. (1984), we conclude that at about $7 \mathrm{hr}$ before ecdysis the declining ecdysteroid titer initiates events that result, about 6 hr later, in an increase in the excitability of the VM cells.

Whether ecdysteroids act directly on the VM cells to change their membrane properties or indirectly by altering the function of undefined neuromodulatory inputs is unknown. Using radiolabeled 20-HE agonists, Bidmon et al. (1991) demonstrated specific, high-affinity binding in large neurons located in the region of the VM cells. This binding was observed over a $3 \mathrm{~d}$ period in the middle of the fifth larval instar, but not in animals selected $6 \mathrm{hr}$ before ecdysis to the fifth instar (1 hr after the nervous system is committed to release $\mathbf{E H}$ ). Their observations, however, do not rule out the presence at the time of commitment of physiologically relevant binding sites that were simply below the detection limits of their method.

\section{Transcription dependence of VM cell excitation}

The long latency between the initiation of events by the steroid decline and the subsequent change in the properties of the VM cells is consistent with a genomically mediated action. We tested this possibility using the transcription inhibitor AcD. During the molt to the pupa, AcD treatment blocks ecdysis when given up to $-6 \mathrm{hr}$, but is ineffective if given thereafter (Truman and Morton, 1990). M. sexta molting to the fifth larval instar behave similarly, although AcD treatment was effective in blocking ecdysis up to $-4.5 \mathrm{hr}$ (Fig. 5). For both stages, the nervous system became insensitive to the $20-\mathrm{HE}-$ induced blockage $2-3 \mathrm{hr}$ before it did to blockage by AcD.

At the pupal and adult molts, the ecdysteroid decline affects both the release of EH and the ability of the nervous system to respond to the neuropeptide (Truman and Morton, 1990). The AcD treatment could affect either or both of these processes. Importantly, larvae treated with AcD at $-6.3 \mathrm{hr}$ were still capable of responding to exogenous EH, even though they did not ecdyse on their own. These results indicate that the pharmacological block interfered with events involved in $\mathrm{EH}$ release and not with events associated with the response to $\mathbf{E H}$. In support of this hypothesis, Figure 6 shows that the $>90 \%$ deplction of EH activity from the ncurohemal relcase sitc that occurs during normal ecdysis (cf. Hewes and Truman, 1991) was not seen in the animals that were treated with AcD.

Associated with this block of $\mathrm{EH}$ release, AcD also blocked the appearance of the suite of electrical changes that occur in the VM cells before ecdysis. Importantly, AcD blocked the induction of these changes. Once they were under way, administration of the drug had no effect (Fig. 7). Given the indirect nature of this pharmacological method, it is possible that the $-6.3 \mathrm{hr}$ injection of AcD produced side effects that blocked the changes in excitability of the VM cells. However, the effects of this $\mathrm{AcD}$ treatment are also consistent with the inhibition of mRNA production necessary for the increase in VM cell excitability. Taken together with the data from the steroid treatments, these results suggest that some transcription-dependent events are initiated by the declining ecdysteroid titer at about $-7 \mathrm{hr}$, are essentially complete by $-4.5 \mathrm{hr}$, and result in the changes in membrane properties that are manifest by $-1 \mathrm{hr}$.

\section{Mechanisms of steroid action in other excitable cells}

The cellular mechanisms underlying genomically mediated effects of steroids on the electrical characteristics of cells have been described in a few systems. These mechanisms are diverse, and include the modulation of voltage- (Kerr et al., 1992; Rendt et al., 1992), ligand- (Erulkar and Wetzel, 1989), and $\mathrm{Ca}^{2+}$-dependent conductances (see Joëls and de Kloet, 1992), induction of mRNAs for ion channels (Boyle et al., 1987; Pragnell et al., 1990; Toro et al., 1990; Levitan et al., 1991), and alteration of the coupling of ligand-gated receptors to their target G-proteins (see Joëls and de Kloet, 1992). Although the ionic conductances leading to the excitation of the VM cells by declining ecdysteroids are as yet undefined, this appears to be the first intracellular demonstration of genomically mediated steroid effects on the excitability of NSCs. EH release from the VM cells triggers a unique, stereotyped motor program, and the coordination of this behavior with the molt-intermolt cycle is well studied. Because the VM cells are identifiable in the isolated nervous system, they are also readily accessible to cellular and molecular analyses. Thus, this system provides a useful model to examine how the 
genomic actions of steroids result in functional changes in NSC activity.

\section{References}

Aldrich RW, Getting PA, Thompson SH (1979) Mechanism of frequency-dependent broadening of molluscan neurone soma spikes. $\mathbf{J}$ Physiol (Lond) 291:531-544.

Araki T, Otani T (1955) Response of single motoneurons to direct stimulation in toad's spinal cord. J Neurophysiol 18:472-485.

Bell RA, Joachim FG (1976) Techniques for rearing laboratory colonics of tobacco hornworms and pink bollworms. Ann Entomol Soc Am 69:365-373.

Bidmon H-J, Granger NA, Cherbas P, Maròy P, Stumpf WE (1991) Ecdysteroid receptors in the central nervous system of Manduca sexta: their changes in distribution and quantity during larval-pupal development. J Comp Neurol 310:337-355.

Boyle MB, MacLusky NJ, Naftolin F, Kaczmarek LK (1987) Hormonal regulation of $\mathrm{K}^{+}$-channel messenger RNA in rat myometrium during oestrus cycle and in pregnancy. Nature 330:373-375.

Copenhaver PF, Truman JW (1982) The role of eclosion hormone in the larval ecdyses of Manduca sexta. J Insect Physiol 28:695-701.

Copenhaver PF, Truman JW (1986) Identification of the cerebral neurosecretory cells that contain eclosion hormone in the moth, Manduca sexta. J Neurosci 6:1738-1747.

Curtis AT, Hori M, Green JM, Wolfgang WJ, Hiruma K, Riddiford LM (1984) Ecdysteroid regulation of the onset of cuticular melanization in allatectomized and black mutant Manduca sexta larvae. $\mathrm{J}$ Insect Physiol 30:597-606.

Dufy B, Partouche C, Poulain D, Dufy-Barbe L, Vincent JD (1976) Effects of estrogen on the electrical activity of identified and unidentified hypothalamic units. Neuroendocrinology 22:38-47.

Eldridge R, Horodyski FM, Morton DB, O'Reilly DR, Truman JW, Riddiford LM, Miller LK (1991) Expression of an eclosion hormone gene in insect cells using baculovirus vectors. Insect Biochem 21:341351 .

Ephrussi B, Beadle AW (1936) A technique of transplantation for Drosophila. Am Nat 70:218-225.

Erulkar SD, Wetzel DM (1989) $5 \alpha$-Dihydrotestosterone has nonspecific effects on membrane channels and possible genomic effects on $\mathrm{ACh}-$ activated channels. J Neurophysiol 61:1036-1052.

Fink G, Rosie R, Sheward WJ, Thomson E, Wilson H (1991) Steroid control of central neuronal interactions and function. J Steroid Biochem Mol Biol 40:123-132.

Frank K, Fuortes MGF (1956) Stimulation of spinal motoneurones with intracellular electrodes. J Physiol (Lond) 134:451-470.

Harlan RE (1988) Regulation of neuropeptide gene expression by steroid hormones. Mol Neurobiol 2:183-200.

Hewes RS, Truman JW (1991) The roles of central and peripheral eclosion hormone release in the control of ecdysis behavior in $\mathrm{Man}$ duca sexta. J Comp Physiol [A] 168:697-707.

Horikawa K, Armstrong WE (1988) A versatile means of intracellular labeling: injection of biocytin and its detection with avidin conjugates. $\mathrm{J}$ Neurosci Methods 25:1-11.

Horodyski FM, Riddiford LM, Truman JW (1989) Isolation and expression of the eclosion hormone gene from the tobacco hornworm, Manduca sexia. Proc Natl Acad Sci USA 86:8123-8127.

Hutchison JB (1991) Hormonal control of behavior: steroid action in the brain. Curr Opin Neurobiol 1:562-570.

Ito $M$ (1957) The electrical activity of spinal ganglion cells investigated with intracellular electrodes. Jpn J Physiol 7:297-323.

Joëls M, de Kloet ER (1992) Control of neuronal excitability by corticosteroid hormones. Trends Neurosci 15:25-30.

Kerr DS, Campbell LW, Thibault O, Landfield PW (1992) Hippocampal glucocorticoid receptor activation enhances voltage-dependent $\mathrm{Ca}^{2+}$ conductances: relevance to brain aging. Proc Natl Acad Sci USA 89:8527-8531.

Krey LC, Silverman AJ (1983) Luteinizing hormone releasing hormone (LHRH). In: Brain peptides (Krieger DT, Brownstein MJ, Martin JB, eds), pp 687-709. New York: Wiley.

Levilan ES, Hemmick LM, Birnberg NC, Kaczmarek LK (1991) Dexamethasone increases potassium channel messenger RNA and activity in clonal pituitary cells. Mol Endocrinol 5:1903-1908.

Mctwen BS (1991) Non-genomic and genomic effects of steroids on neural activity. Trends Pharmacol Sci 12:141-147.
McEwen BS, Parsons B (1982) Gonadal steroid action on the brain: neurochemistry and neuropharmacology. Annu Rev Pharmacol Toxicol 22:555-598.

McEwen BS, Coirini H, Danielsson A, Frankfurt M, Gould E, Mendelson S, Schumacher M, Segarra A, Woolley C (1991) Steroid and thyroid hormones modulate a changing brain. J Steroid Biochem Mol Biol 40:1-14.

Miles CI, Weeks JC (1991) Developmental attenuation of the preecdysis motor pattern in the tobacco hornworm, Manduca sexta. $\mathrm{J}$ Comp Physiol [A] 168:179-190

Miyazaki S (1980) The ionic mechanism of action potentials in neurosecretory cells and non-neurosecretory cells of the silkworm. J Comp Physiol 140:43-52.

Naftolin F, MacLusky NJ, Leranth CZ, Sakamoto HS, Garcia-Segura LM (1988) The cellular effects of estrogens on neuroendocrine tissues. J Steroid Biochem 30:195-207.

Orchard I, Loughton BG (1985) Neurosecretion. In: Comprehensive insect physiology, biochemistry and pharmacology, Vol 7 (Kerkut GA, Gilbert LI, eds), pp 61-107. New York: Pergamon.

Pichon Y, Ashcroft FM (1985) Nerve and muscle: electrical activity. In: Comprehensive insect physiology, biochemistry and pharmacology, Vol 5 (Kerkut GA, Gilbert LI, eds), pp 85-113. New York: Pergamon.

Pragnell M, Snay KJ, Trimmer JS, MacLusky NJ, Naftolin F, Kaczmarek LK, Boyle MB (1990) Estrogen induction of a small, putative $\mathrm{K}^{+}$channel mRNA in rat uterus. Neuron 4:807-812.

Rendt JM, Toro L, Stefani E, Erulkar SD (1992) Progesterone increases $\mathrm{Ca}^{2+}$ currents in myometrial cells from immature and nonpregnant adult rats. Am J Physiol 262:C293-C301.

Reynolds SE, Taghert PH, Truman JW (1979) Eclosion hormone and bursicon titres and the onset of hormonal responsiveness during the last day of adult development in Manduca sexta (L). J Exp Biol 78: $77-86$.

Riddiford LM, Truman JW (1978) Biochemistry of insect hormones and insect growth regulators. In: Biochemistry of insects (Rockstein M, ed), pp 307-357. New York: Academic.

Saphier D, Feldman S (1990) Iontophoresis of cortisol inhibits responses of identified paraventricular nucleus neurons to sciatic nerve stimulation. Brain Res 535:159-162.

Schumacher M (1990) Rapid membrane effects of steroid hormones: an emerging concept in neuroendocrinology. Trends Neurosci 13: $359-362$.

Terzi G, Truman JW, Reynolds SE (1988) Purification and characterization of eclosion hormone from the moth, Manduca sexta. Insect Biochem 18:701-707.

Toro L, Stefani E, Erulkar S (1990) Hormonal regulation of potassium currents in single myometrial cells. Proc Natl Acad Sci USA 87:28922895.

Trimmer BA, Weeks JC (1989) Effects of nicotinic and muscarinic agents on an identified motoneurone and its direct afferent inputs in larval Manduca sexta. J Exp Biol 144:303-337.

Truman JW (1972) Physiology of insect rhythms. I. Circadian organization of the endocrine events underlying the moulting cycle of larval tobacco hornworms. J Exp Biol 57:805-820.

Truman JW (1992) The eclosion hormone system of insects. In: Progress in brain research, Vol 92 (Joosse J, Buijs RM, Tilders FJH, eds), pp 361-374. New York: Elscvicr.

Truman JW, Copenhaver PF (1989) The larval eclosion hormone neurones in Manduca sexta: identification of the brain-proctodeal neurosecretory system. J Exp Biol 147:457-470.

Truman JW, Morton DB (1990) The eclosion hormone system: an example of coordination of endocrine activity during the molting cycle of insects. Prog Clin Biol Res 342:300-308.

Truman JW, Taghert PH, Reynolds SE (1980) Physiology of pupal ecdysis in the tobacco hornworm, Manduca sexta. I. Evidence for control by eclosion hormone. J Exp Biol 88:327-337.

Truman JW, Taghert PH, Copenhaver PF, Tublitz NJ, Schwartz LM (1981) Eclosion hormone may control all ecdyses in insects. Nature 291:70-71.

Truman JW, Rountree DB, Reiss SE, Schwartz LM (1983) Ecdysteroids rcgulatc the relcase and action of eclosion hormone in the tobacco hornworm, Manduca sexta (L.). J Insect Physiol 29:895-900.

Zimmerman EA (1983) Oxytocin, vasopressin, and neurophysins. In: Brain peptides (Krieger DT, Brownstein MJ, Martin JB, eds), pp 597 611. New York: Wiley. 